\title{
AS INÚMERAS FACES DA VIOLÊNCIA DITATORIAL NA AMÉRICA LATINA NOS ANOS 1960 E 1970
}

\author{
Fábio José de Queiroz ${ }^{1}$
}

\begin{abstract}
RESUMO
O objetivo deste artigo é refletir sobre a violência institucionalizada na América Latina, nos anos 1960 e 1970, tomando como referência os casos de Paraguai, Brasil, Uruguai, Chile e Argentina, que requerem um tratamento analítico, simultaneamente, individualizado e articulado, em que as analogias históricas se mostram úteis, não somente para identificar as similaridades, mas, do mesmo modo, situar as especificidades das experiências autocráticas; adota-se, aqui, um procedimento metodológico que se assenta, fundamentalmente, na revisão da literatura que, direta ou indiretamente, se inclina à análise histórica desse período de afirmação de poderes ditatoriais e de coação militar aberta, considerando os relatos jornalísticos, os estudos históricos e as apreciações políticas e sociológicas acerca do tema; do estudo bibliográfico, e à luz de interpretação teórica de caráter marxista, resulta uma enunciação explícita e ampliada do caráter autocrático e brutal do militarismo, ao tempo que se ratifica a necessidade de uma recuperação crítica dos "anos de chumbo" - e de suas modalidades específicas de violência sob o manto da Doutrina de Segurança Nacional (DSN) - no território latino-americano.
\end{abstract}

Palavras-chave: América Latina, Militarismo, Ditadura. Violência.

\begin{abstract}
The purpose of this paper is to discuss the institutionalized violence in Latin America in the 1960s and 1970s, by reference to cases of Paraguay, Brazil, Uruguay, Chile and Argentina, which require an analytic treatment simultaneously individualized and articulated, in which historical analogies prove to be useful, not only to identify similarities, but, likewise, place the specificities of autocratic experiences in question; it is adopted, here, a methodological approach which is essentially based on the literature review that directly or indirectly leans to the historical analysis of this statement period of dictatorial powers and open military coercion, considering the journalistic reports, historical studies and political and sociological assessments on the theme; from the bibliographic study, and in light of Marxist character theoretical interpretation, results an explicit and extended enunciation of the repressive and brutal character of militarism, at the time it confirms the need for a critical recovery of the "years of lead" - and its specific modalities of violence under the cover of National Security Doctrine (NSD) - of the Latin American territory.
\end{abstract}

Keywords: Latin America. Militarism. Dictatorship. Violence.

\footnotetext{
${ }^{1}$ Doutor em Sociologia (UFC), Professor Adjunto do Departamento de História da Universidade Regional do Cariri (URCA), na qual é coordenador do Grupo de Pesquisa "Marx, luta de classes, Estado, ideologia e revolução". E-mail: fabiojosequeiroz@yahoo.com.br.
} 


\section{INTRODUÇÃO}

Tive que contar os meus dias para não ser esmagado por eles (Amadeu, personagem do filme Trem noturno para Lisboa).

Leon Tolstoi escreve que "todas as famílias felizes são parecidas entre si. As infelizes são infelizes cada uma a sua maneira". No livro que escrevi sobre o golpe de 1964, no Brasil, acrescento que, no terreno da história do militarismo dos anos 1960 e 1970, na América Latina, todos os episódios são parecidos entre si, e todos são infelizes, cada um à sua maneira. (QUEIROZ, 2015).

Neste trabalho, tomo como referência o estudo das experiências autocráticas, de verniz militar, em países bem distintos como o Paraguai, o Brasil, o Chile, o Uruguai e a Argentina. Não se trata de estudar esses processos históricos em sua complexidade e inteireza, mas de recobrar e enfatizar as inúmeras faces da violência ditatorial na América Latina nos anos de chumbo.

Se, em linguagem marxista, a violência é a parteira de uma sociedade velha grávida de uma nova, ela também pode ser a parteira de grandes retrocessos históricos.

\section{A PRÉ-HISTÓRIA DAS DITADURAS: O CASO PARAGUAIO}

Embora o auge do sistema de poder ditatorial seja registrado nos anos 1960 e 1970, há de se admitir que ele tenha toda uma longa pré-história, que, nos anos 1950, se desvela em acontecimentos trágicos como os golpes de Estado de 1954, o primeiro na Guatemala, com a deposição do governo nacionalista de Jacob Arbenz Guzmán, e o segundo no Paraguai, que promove a ascensão ao poder do general Alfredo Stroessner, que governa o país vizinho durante 35 anos. Isso sem se esquecer do golpe militar que depõe Perón, em 1955, na Argentina. Agrego que, no caso do Brasil, o suicídio de Getúlio Vargas breca a operação golpista que, naquele momento, se articula à volta do Catete.

Dessa pré-história, parece-me relevante estudar o problema da violência no Paraguai, uma vez que a brutalidade que perpassa a ditadura do Stroessner permeia os anos 1960 e 1970, se estendendo até a sua derrubada, em 1989.

Politicamente amparado no Partido Colorado, e fisicamente, nas FFAA, Alfredo Stroessner usa da violência não somente para depor o governo do presidente Francisco Chaves, mas elimina progressivamente outros grupos adversários no interior do próprio partido, com exceção do grupo do Natalício Gonzalez, líder dos guionistas (Guión Rojo), que

\begin{tabular}{|l|l|l|l|l|}
\hline Qevista Dialectus & Ano 2 & n.7 & Setembro-Dezembro 2015 & p. $104-126$ \\
\hline
\end{tabular}


não se furta de utilizar a violência física contra os opositores. Essa característica do grupo guionista e a necessidade do ditador de contar com os seus préstimos, faz com esse agrupamento político, adepto de métodos de guerra civil contra os adversários, se ache preservado por maior tempo em sua integridade política e física. Na realidade, são os guionistas que organizam o aparato repressivo do regime ditatorial paraguaio, se bem que, no curso dos acontecimentos, representantes do grupo, assim como o seu líder, não sejam inteiramente preservados da fúria repressora da ditadura.

Evidentemente, o controle político é empregado sobremaneira para sepultar a resistência dos opositores do general que militam fora do Partido Colorado. Destaco o caso da repressão aos adversários internos como modo de demonstrar o caráter quase pessoal e abusivo da ditadura no Paraguai. Diria que o caso paraguaio se aproxima mais de situaçõeslimite como a de Cuba, com Fulgêncio Batista, e, da Nicarágua, com a família Somoza. Nesses casos, a conjugação poder militar e ditadura unipessoal é uma realidade. De certa maneira, nesses países, em momentos muito próximos, o militarismo e o poder familiar compõem uma complexa rede de dominação política. Não por acaso, as famílias Batista, Somoza e Stroessner, respectivamente, se tornam as mais ricas linhagens de Cuba, Nicarágua e Paraguai. ${ }^{2}$ Para isso, não economizam energia na aplicação da estratégia da violência como parte inerente do sistema de poder que adotam. De todos esses governos, não se espere a realização do desígnio de Hobbes (1993) de um árbitro ou juiz que as pessoas discordantes instituem por consentimento, concedendo-lhe o direito à sentença. Nessas circunstâncias, são árbitros impostos e resolvidos a obrigar as pessoas a aceitar o que eles sentenciam. Do abjeto não nasce a beleza, mas a violência.

Aqui, me interessa examinar o caso paraguaio.

O stronismo ${ }^{3}$ é um dos tantos fundamentalismos anticomunistas nascidos do ventre da "Guerra Fria". A sua selvajaria é intrínseca a sua doutrina. Os principais alvos da violência ditatorial são os sindicatos, as organizações camponesas e as entidades estudantis que, segundo Bouvier (1988, p. 18), de fato, são infiltrados, subornados ou simplesmente destruídos. As formas de violência variam: demissões, exílio, torturas, prisões, espancamentos, sequestros e assassinatos. Essa violência do stronismo também apresenta

\footnotetext{
${ }^{2}$ A família Stroessner contabiliza uma renda no exterior superior a cinco bilhões de dólares. Quando se sabe da pobreza que afeta o Paraguai, não há como não enxergar aí um caso particular de violência social e econômica.

${ }^{3}$ O longo período de domínio de Alfredo Stroessner, na esfera do Estado nacional guarani, insere no vocabulário político esse neologismo que, chama a atenção para as peculiaridades do padrão da matriz paraguaia no aglomerado de ditadores latino-americanos. Aqui, evidentemente, não há espaço para uma apreciação mais minuciosa das características desse fenômeno particular do autocratismo.
}

\begin{tabular}{|l|l|l|l|l|}
\hline Qonista Dialectus & Ano 2 & n.7 & Setembro-Dezembro 2015 & p. 104-126 \\
\hline
\end{tabular}


traços pitorescos, como a obrigação dos servidores públicos de se filiar ao Partido Colorado e doar 5\% da sua remuneração ao mencionado partido. Talvez Bourdieu tratasse tal modalidade de violência como especificamente simbólica. O importante, no entanto, é enfatizar a amplitude das formas de hostilidade aplicadas pelo stronismo.

A orientação que guia o aparelho repressivo da ditadura Stroessner parte do pressuposto de que "o controle da oposição seria facilitado na medida em que a polícia perseguisse, prendesse e torturasse toda pessoa que representasse algum tipo de perigo para as estruturas estatais" (Santos, 2013, p. 42). A ditadura stronista usa também o Estado de Sítio como modo de controlar a população e consolidar o seu domínio. Isso demonstra que os instrumentos normais de coerção se mostram insuficientes no sentido de conferir estabilidade ao regime autocrático. Os estudiosos da história paraguaia, de ordinário, admitem que o Estado de Sítio seja uma prática de contínuo retorno durante os mais de 30 anos de ditadura. Os Milicianos da Guarda Urbana, na vigência do Estado de Sítio, entram em qualquer casa e prendem qualquer pessoa "que fosse considerada suspeita de agir contra o governo". (LEWIS apud Santos, 2013, p. 45).

Além disso, na Nação Meridional do Prata, em um determinado momento, nem os padres escapam do rompante repressivo, o que induz a Igreja Católica, que apoia o regime durante longo tempo, a denunciar a violência perpetrada pela polícia e pelos milicianos da Guarda Urbana.

Rossi (1980) caracteriza o regime ditatorial paraguaio como "precursor artesanal dos regimes de Segurança Nacional", mas há se consentir e esclarecer que essa aparelhagem artesanal resulta em uma produção, de escala industrial, no tocante à violência contra a população. O caráter industrial da violência da ditadura stronista pode ser percebido, por exemplo, na resistência armada, como a promovida pelo Partido Comunista do Paraguai, que cria a Frente Unida de Liberação Nacional (FULNA), na primeira metade dos anos 1960. A ditadura convoca os camponeses para que assistam o fuzilamento dos guerrilheiros. Esse é o modo encontrado para desalentar os camponeses que sonhassem em aderir a grupos insurgentes.

A ditadura e os latifundiários brasileiros são partes constituintes dessa violência. $\mathrm{O}$ exército paraguaio mata os camponeses e as suas terras ficam disponibilizadas para serem vendidas aos fazendeiros do Brasil. Surge aí a figura dos brasiguaios.

A descoberta dos arquivos da policia paraguaia, em 1992, representa não apenas um salto para reconstituição da dramática história do período de dominação oligárquico-militar na

\begin{tabular}{|c|c|c|c|c|}
\hline Q Rovista Dialectus & Ano 2 & n.7 & Setembro-Dezembro 2015 & p. 104-126 \\
\hline
\end{tabular}


terra de Francisco Solano López, mas trouxe a luz elementos que permitem analisar o intercâmbio do terror na América do Sul, nos anos de chumbo. O arquivo contém 700 mil folhas com informações sobre a ditadura de Alfredo Stroessner. Nesse arquivo, 10 mil fotografias, centenas de fitas gravadas e documentos diversos revelam como o sistema repressivo busca ter o controle absoluto da informação com relação aos que se opõem ao poder ditatorial. Os "arquivos do terror" atestam a colaboração dos governos ditatoriais sulamericanos, por intermédio de ações comuns, e a sua documentação ajuda a esclarecer casos que, até então, pareciam indecifráveis e contribuem para a punição de muitos agentes do esquema repressivo, particularmente na Argentina, Chile e Paraguai.

Essa documentação comprova a existência da Operação Condor, uma articulação dos governos ditatoriais com o intento de combater os seus opositores, usando mão da colaboração mais infame e da violência mais extrema. Cem mil pessoas, no Cone Sul da América Latina, compõem a lista macabra da Operação Condor.

No Paraguai, um dos casos mais conhecidos diz respeito ao médico Agostín Goiburú, emboscado e sequestrado na Argentina, onde se encontra exilado, e assassinado, em março de 1977, na presença do ditador Alfredo Stroessner. Goiburú pertence ao Movimento Popular Colorado. (MOPOCO).

É evidente que esse caso é somente a ilustração particular da violência contra quase 1/3 da população do país, em geral, detida, deportada ou simplesmente assassinada pela lógica repressiva do sistema de poder militar-oligárquico. A violência estatal não poupa operários, camponeses, estudantes, intelectuais e outras parcelas da sociedade. Doutro lado, as garantias individuais são atiradas às calendas gregas. $\mathrm{O}$ arbítrio se torna regra e a liberdade queda refém do alvedrio militar-oligárquico. O medo se espalha e a população, por um tempo, se dispersa. Depois se recompõe e começa a travar um combate aberto contra a ditadura, o que encaminha o Partido Colorado, os militares e o empresariado a uma solução que põe fim ao demasiado extenso período do stronismo. Para se safar da punição, Alfredo Stroessner se exila no Brasil e, aqui, vive afortunadamente os seus últimos anos de vida, o que não deixa de ser a última das violências associadas a essa personagem do anedotário latino-americano, com os seus ditadores, os seus patriarcas e os seus coronéis para os quais ninguém escreve (como na bela narrativa de Gabriel García Márquez).

Se o Paraguai tem a peculiaridade de presenciar a ascensão da ditadura, em 1954, e de acompanhá-la nos anos 1960 e 1970, é o país que espera até 1989, para, finalmente, testemunhar a queda do sistema de poder militar-oligárquico articulado em torno da figura

\begin{tabular}{|l|l|l|l|l|}
\hline Qonista Dialectus & Ano 2 & n.7 & Setembro-Dezembro 2015 & p. 104-126 \\
\hline
\end{tabular}


obscura, definitivamente sinistra, de Alfredo Stroessner. Por mais paradoxal que pareça, o conservadorismo segue no poder, mas, agora, sem o oligarca-mor.

Este é o primeiro capítulo de uma soma de capítulos de terror e violência.

\section{OS GOLPES MILITARES DOS ANOS 1960: O CASO BRASILEIRO}

O que aqui chamo de segundo capítulo, de feito, é a antessala do primeiro ato de uma série de terror e violência. Refiro-me ao Brasil. Em 1964, o golpe de Estado não significa somente a modelagem de um novo bloco de poder, mas de uma nova forma de dominação política, assentada sobre as ruínas da classe trabalhadora.

Passados mais de cinquenta anos do golpe de Estado, do dezoito de brumário da burguesia brasileira, os números frios da violência oficial revelam que a classe trabalhadora é a maior vítima da ditadura empresarial-militar. Das 437 pessoas que constam nas listas de "Mortos e Desaparecidos Políticos", 248 (56\% do total) são trabalhadores. Tomando e destrinchando esses números funestos, notamos que a maioria é constituída de operários (55 ao todo). Além do operariado, há forte presença de camponeses (40), professores (23), bancários (17) e jornalistas (12). Irredutivelmente, esse é o quadro.

Note-se que aqui se enuncia números oficiais. Com efeito, os números são mais dramáticos e extensos. Por exemplo, falta se contabilizar a cifra de indígenas assassinados pela ditadura no Brasil. Os números oficiais são subestimados. Nesse sentido, é um disparate se pronunciar a respeito de uma suposta ditabranda no Brasil.

Do mesmo modo, é um desserviço à história a hipótese do Sr. Elio Gaspari sobre a existência de uma ditadura envergonhada nos primeiros anos de domínio militar. A “Operação Limpeza", é produto direito do Golpe de Estado e da introdução da ditadura empresarialmilitar. Recomendo que se leia as Memórias de velho comunista Gregório Bezerra. A edição mais recente traz anexo poema de Ferreira Gullar que descreve com acuidade o drama de Gregório, arrastado pelas ruas do Recife, logo depois do putsch:

“... e Gregório/Foi, de maneira ultrajante./Amarrado como um bicho/que o levou pro Recife/Às ordens do comandante". (2011, p. 631):

Mais adiante, Gullar (p. 631) relata:

Darci Villocq Viana, eis o nome do vilão.

Esse coronel do Exército

\begin{tabular}{|l|l|l|l|l|}
\hline Q Rovista Dialectus & Ano 2 & n.7 & Setembro-Dezembro 2015 & p. 104-126 \\
\hline
\end{tabular}


mal viu Gregório chegar partiu pra cima dele

e o começou a espancar.

Bateu com um cano de ferro na cabeça até sangrar.

Chamou outros subalternos para o preso massacrar. Gritando: "Bate na fera! Bate, bate, até matar!"

Dava pulos e babava como se fosse endoidar.

Despois despiram Gregório e já dentro do xadrez com a mesma fúria voltaram a espancá-lo outra vez. Com 70 anos de idade e outros tantos de altivez, nenhum gesto de clemência ao seu algoz ele fez.

$\mathrm{O}$ sangue agora o cobria da cabeça até os pés.

No chão derramaram ácido e fizeram ele pisar. A planta dos pés queimava, mal podia suportar.

Vestiram-lhe um calção para depois o amarrar com três cordas no pescoço e para a rua o levar preso à traseira de um jipe

e para ao povo mostrar

o "bandido comunista" que se devia linchar. Estava certo Villocq que o povo o ia apoiar para em plena praça pública

o comunista enforcar...

Mas para seu desespero o povo não o apoiou. Aos seus apelos de "enforca!"

nenhuma voz se juntou.

Um silêncio insuportável sua histeria cercou.

Via era ódio nos olhos

e se ninguém protestou é que os soldados em volta ao povo impunham terror. Muitas mulheres choravam. Uma freira desmaiou no Largo da Casa Forte onde o cortejo parou.

"Meus pés eram duas chagas - Gregório mesmo contou e no meu pescoço a corda ainda mais apertou.

\begin{tabular}{|l|l|l|l|l|}
\hline Q & Anoista 2 & n.7 & Setembro-Dezembro 2015 & p. $104-126$ \\
\hline
\end{tabular}


O sangue que me banhava minha vista sombreou.

Senti que a força faltava mas minha boca falou:

"Meu povo inda será livre!" E muita gente chorou no Largo da Casa Forte onde o cortejo parou.

O episódio que Gullar reconstitui em seus versos não representa um caso isolado. Se a ditadura é envergonhada, ela não se envergonha de impor flagício em público a um quase octogenário.

No livro "Brasil, nunca mais”, lê-se a seguinte síntese pungente de Philip Potter: “... a tortura é o crime mais cruel e bárbaro contra a pessoa humana" (p. 17) e "os torturadores são agentes conscientes desse ato degradante" (Idem). A começar de 1964, a tortura se erige em política de Estado, e os agentes da repressão não se envergonham de supliciar os opositores do golpe em plena luz do dia, como demonstra o episódio no qual refulge a pessoa do Gregório Bezerra.

Não se tome as FFAA como um bloco monolítico. Estudando os arquivos da ditadura, nota-se que houve resistência ao golpismo no âmbito das Forças Armadas. Castelo Branco, como represália, reforma compulsoriamente 77 oficiais do exército, 14 da marinha e 31 da aeronáutica. Paralelamente, a máquina estatal passa por uma autêntica devassa e dez mil funcionários públicos são demitidos. Em um desenho mais amplo, e de uma maneira totalmente simétrica, 40 mil pessoas são, de imediato, colocadas na condição de investigadas. Nasce o SNI. Eis a ditadura envergonhada do Sr. Gaspari.

Nos dias que seguem ao golpe de primeiro de abril de 1964, até uma prisão flutuante é usada para confinar sindicalistas e líderes políticos de oposição à usurpação militarista. $\mathrm{O}$ navio Raul Soares vaga durante, aproximadamente, seis meses, carregando em sua podridão física o empenho dos golpistas em desmoralizar e quebrar a resistência dos seus oponentes. Trata-se de um exemplo caricato? Não, a ditadura em si é uma caricatura, pois as suas personagens, os seus gestos, as suas palavras, absolutamente tudo, em suma, compõem um museu de peças caricatas, ainda que seja um museu de minoridade moral e política.

Na obra "Os filhos do dia", de autoria do Eduardo Galeano, há diversos exemplos de violência perpetrados nos anos sombrios da ditadura no Brasil. Não há por que não ilustrara essa exposição com algumas das passagens desse livro brilhante.

Ás vésperas do golpe de Estado, trabalhadores da cidade e do campo lutam, se organizam, e, mediante as suas experiências de classe, aprendem. Galeno (2014) conta que,

\begin{tabular}{|c|c|c|c|c|}
\hline Rovista Dialectus & Ano 2 & n.7 & Setembro - Dezembro 2015 & p. $104-126$ \\
\hline
\end{tabular}


pouco antes do golpe triturar as esperanças de milhões, Paulo Freire se encontra no estado de Sergipe, levando a sua pedagogia para camponeses analfabetos. Lá ele conhece João, que um dia aparece silencioso e é questionado pelo educador devido o seu longo silêncio, e depois de uma pausa, João responde: "Não consegui dormir. A noite inteira sem fechar os olhos". Paulo Freire tenta entender o que está acontecendo, até que João lhe explica: “Ontem, eu escrevi o meu nome pela primeira vez". Esse é um processo interrompido pela usurpação militarista de 1964. É contra esse tipo de processo que se levantam militares e burgueses. São poucos os exemplos de violência que tenham a força desse caso.

Assim, desde o princípio, o poder ditatorial não se mostra envergonhado. É uma ditadura abertamente bonapartista, com traços semifascistas, e que, à medida que a resistência se eleva, ela também amplia e aprofunda os seus métodos de violência e ferocidade. Não é a resistência de grupos armados que introduz a violência como traço inelutável do regime. Essa violência é característica que provém do parto.

No livro "Tiradentes, um presídio da ditadura", nota-se que parte dos presos políticos se organiza em agrupamentos que lutam contra o regime dos generais, mas sem, necessariamente, preconizar o instrumento da luta armada, sugerindo a ação de massa como estratégia principal de combate ao autocratismo. Acontece que, independentemente da estratégia defendida, os militantes e grupos sofrem repressão semelhante. Logo, não é a forma de luta contra o regime que define o caráter desse último. Esse caráter está definido desde o primeiro momento. A repressão e a violência política são traços inerentes à ditadura bonapartista nascida do putsch de 1964.

Veja-se o caso do pernambucano Júlio Tavares, militante da Fração Bolchevique Trotskista. O seu depoimento confirma a virulência do regime:

Quando chegamos ao DEOPS fomos levados para uma sala onde nos bateram duramente. Em certo momento, me levaram para outra sala, em outro andar, onde fui despido, amarrado, amordaçado e colocado no pau-dearara. Os torturadores pareciam enlouquecidos. (1997, p. 305).

Dramático é saber que, encerrado o longo ciclo dos generais, essas práticas permanecem como modalidades regulares de funcionamento dos órgãos da segurança pública do país. A violência parece não respeitar os ciclos, chame-se ele "ciclo dos generais" ou chame-se ele "ciclo da democracia".

\begin{tabular}{|c|c|c|c|c|}
\hline QRovista Dialectus & Ano 2 & n.7 & Setembro - Dezembro 2015 & p. $104-126$ \\
\hline
\end{tabular}


O fato é que a selvajaria e a bestialidade, no plano político, se ostentam como o que, em última análise, define o perfil dos regimes que dominam a América Latina nos anos 1960 e 1970, embora, no limite, essas formas de ordem política se perpetuem até a década de 1980. Nessa forma de dominação política, a repressão não é um acidente de percurso. Trata-se de um modelo sistemático de conduta. Nesse modelo, a tortura adquire ares de "cientificidade". A esse respeito, é representativo dos estudos em torno a esse tema, o livro "Tortura - a história da repressão política no Brasil”, do Antônio Carlos Fon. Na obra, o autor descreve, inclusive, as condições por ele vividas nos porões da ditadura:

Fui levado para a câmara de torturas, no segundo andar, e durante três horas submetido a "pau-de-arara", espancamentos e choques elétricos. De tudo isso, lembro-me de que nada era mais terrível que os choques elétricos na cabeça, com um fio preso no lóbulo da orelha e outros percorrendo os lábios, o pescoço ou o nariz. Esses choques provocam uma contração tão forte dos músculos da face que a língua é estraçalhada pelos dentes.

(...)

Fiquei 17 dias na "Operação Bandeirantes". Se o inferno existe, a "Operação Bandeirantes” é pior. (FON, 1979, p. 11).

No livro, o autor relata múltiplos casos de violência contra os presos políticos da ditadura. A sua prisão ocorre em 1969, pouco tempo depois de Costa e Silva decretar o Ato Institucional n.5. O livro é publicado 10 anos depois e é útil para demonstrar o significado mais profundo de um regime político em que a luz é o porão. Há exemplos de que a violência da ditadura, dentre outras coisas, promove a desumanização, como no caso de um pintor preso na OBAN, cuja situação é descrita por Antônio Carlos Fon, nos seguintes termos:

Dramática era a situação do pintor Suzuki. Depois de quinze dias sendo torturado e vendo outros homens sendo torturados, Suzuki chegou à conclusão de que a humanidade havia regredido e que éramos todos animais. Nos dias seguintes, enlouqueceu e passou a agir como se fosse um macaco. Ficava nu, pendurado nas grades da cela e se recusava a comer outra coisa que não fosse amendoim ou banana. (Idem, p. 13).

A base jurídico-filosófica de toda essa monstruosidade, se é que isso pode ser levado a sério, é a noção de segurança nacional, ideia que cimenta a implantação de regimes discricionários, nesse período, em praticamente toda a América do Sul, salvo Venezuela e Colômbia, onde os governos são tão conservadores e autoritários que parece não ser necessário instituir um tipo de sistema de poder militar. Essa suposta base jurídico-filosófica é fomentada pelos Estados Unidos que, rigorosamente, não se acanham de, em todos esses casos, auxiliar governos que pisoteiam a democracia representativa que apregoam encarnar. A 
participação da embaixada dos EUA no golpe militar, no Brasil, inclusive articulando a “Operação Brother Sam”, é parte da introdução de uma ditadura cujo único escrúpulo é não ter escrúpulo algum.

Além da tortura "cientificamente" institucionalizada, das perseguições e prisões arbitrárias, da transformação do Estado Militar em Cárcere do povo, do exílio, dos assassinatos, os órgãos de segurança usam e abusam do expediente da infiltração nas organizações de esquerda, que perdem muitos de seus militantes por obra e graça da introdução da figura do "cachorro" no interior desses agrupamentos. O caso mais célebre é o do cabo Anselmo. Infiltrado na Vanguarda Popular Revolucionária (VPR), ele é o principal responsável pelo Massacre da Chácara São Bento, nos arredores de Recife, que acaba na morte de seis militantes, dentre eles, da sua companheira, a militante paraguaia Soledad Barret, possivelmente grávida de seu delator.

Ao restaurar para a história esse trágico acontecimento, Eduardo Galeano escreve:

\footnotetext{
O cabo Anselmo, marinheiro insurgente, chefe revolucionário, foi quem a entregou. Cansado de ser perdedor, arrependido de tudo o que acreditava e gostava, ele delatou um por um seus companheiros de luta contra a ditadura militar brasileira e os despachou para o suplício ou o matadouro. Soledad, que era sua mulher, ele deixou para o fim. O cabo Anselmo apontou o lugar onde ela se escondia e foi-se embora. Já estava no aeroporto quando ouviram-se os primeiros tiros. (EDUARDO GALEANO, 2014, p. 21).
}

Os policiais desfecham 26 tiros nos seis militantes da VPR, sendo que 14 deles na cabeça. A execução, um dos traços do regime discricionário, mostra a sua face mais ríspida e selvagem. Soledad é uma das tantas mulheres que morrem no combate à ditadura e deixa o seu nome registrado. Estima-se, por baixo, que cinquenta mulheres são mortas, nos anos de chumbo, pelas mãos do poder autocrático instalado no país.

Dos quase 500 nomes oficiais de mortos e desaparecidos da ditadura, no Brasil, mais de $10 \%$ são de mulheres, que confrontam um sistema de poder que, na medida em que protege o grande capital, não se ruboriza de praticar os crimes mais hediondos contra operários, camponeses, estudantes, índios e mulheres. Mesmo a Igreja Católica, que apoia o golpe de força de 1964, gradativamente, passa a sofrer com a violência ditatorial, conforme se desprende de casos emblemáticos como o de Frei Tito e do padre Henrique.

No caso de Frei Tito, segundo Ben Strik ele “já tinha morrido depois das torturas. Durante três anos lutou contra isso, até não poder mais suportar" (2009, p. 23). Já o padre Henrique, sofre também as dores da tortura, da sevícia e da morte, e sofre, também, o fato de 
se ligar à figura de dom Hélder Câmara, considerado pela ditadura como uma espécie de "bispo vermelho".

Nos anos 1970, a Igreja Católica começa um lento giro que se conclui com a sua passagem à oposição ao regime dos generais. São os tempos da política dos direitos humanos. Toda a sua superestrutura rodopia em volta de um eixo: o da impugnação da ditadura. As lutas operárias conferem uma nova dimensão ao combate contra o regime ditatorial e a juventude estudantil retoma as suas entidades, as reorganiza e reforça as linhas de confronto com relação ao autoritarismo vigente. Com a campanha das diretas, o isolamento do poder militar alcança níveis mais abrangentes. O governo Figueiredo sai pelo fundo do palácio. Para os compositores Ivan Lins e Vitor Martins, o país se encontra perante "um novo tempo, apesar dos perigos".

Ainda que se pudesse falar de "um novo tempo", não há como não enfatizar o balanço histórico do tempo que se dissipa. Trata-se, em última análise, de se acertar as contas pendentes com a história, com tempos de dor e de luta, de túmulos sem nomes e de nomes sem túmulos, como bem o disse Galeano, e que, particularmente, no caso do Brasil, se traduz em 5 000 cassados, 50000 presos, 10000 exilados, 7000 mil processados, 10000 torturados e oficialmente, 437 mortos e desaparecidos. O que, para alguns, pode ser uma piada estética cruel, simples formação discursiva ou meras formas estatísticas, para os que sofrem os efeitos da "pax militar", é a crueldade elevada à categoria de ordem política.

\section{OS GOLPES MILITARES DOS ANOS 1970: OS CASOS DE CHILE, URUGUAI E ARGENTINA}

Se, nos anos 1960, o cenário é bastante cinza para as populações latino-americanas, esse horizonte nublado se espalha e se estende na década seguinte. O caso chileno é emblemático, até porque a tradição civilista e constitucionalista desse país parece representar um obstáculo perante possíveis vicissitudes do quadro político. A vitória da Unidade Popular na eleição presidencial de 1970 conduz Salvador Allende, do Partido Socialista, à chefia do executivo nacional. $\mathrm{O}$ seu mandato defronta uma reação coordenada das classes dominantes chilenas, da alta cúpula das FFAA e da CIA e acaba em 11 de setembro de 1973, mediante um sangrento golpe, comandado por um ministro militar de seu governo: Augusto Pinochet. Começam os tempos mais sombrios da história política chilena.

Sobre o golpe e os dias que se seguem a esse ato, há duas visões que merecem ênfase: a do latino-americanista francês Alain Rouquié e a da jornalista chilena Patrícia Verdugo.

\begin{tabular}{|l|l|l|l|l|}
\hline Govista Wialectus & Ano 2 & n.7 & Setembro-Dezembro 2015 & p. $104-126$ \\
\hline
\end{tabular}


Para Rouquié (1984), “o golpe de Estado de 11 de setembro de 1973 foi um dos mais sangrentos que o continente conheceu. Chegou-se a falar de 35000 mortos, dentre os quais o Presidente Allende...". (p. 266). O "Estado de compromisso" é varrido das vistas de milhões de habitantes do Chile, perfurado de morte pela sociedade militar, adestrada pelas escolas estadunidenses: "De 1950 a 1970, 4374 militares chilenos foram preparados no Panamá e nos Estados Unidos" (ROUQUIÉ, 1984, p. 287). Esse fato está na base do Estado Militar que se ergue no Chile sobre os escombros da democracia.

Certamente, houve resistência nas Forças Armadas contra o golpismo furioso e só isso explica os 2000 mortos entre os militares e carabineiros, conforme relata Alain Rouquié (p. 305), embora sejam os civis, e sobremaneira os militantes de esquerda, as principais vítimas da carnificina inerente ao pinochetazo. Nessa perspectiva,

O Golpe de Estado de 11 de setembro é uma verdadeira ruptura histórica, selada pelo sangue das vítimas. Para salvar o país do "câncer marxista" e "proteger a democracia", o Exército quebra o "Estado de compromisso" sem deixar possibilidade de retorno, e proclama o "Estado de sítio", designandose um poder tutelar. (ROUQUIÉ, 1984, p. 305/306).

· No Estádio Nacional, milhares são torturados, outros tantos são mortos. O assassinato do artista chileno Victor Jara é um símbolo da violência que se funde com as primeiras horas, os primeiros dias e os primeiros tempos do pinochetismo. Pior: essas primeiras horas, esses primeiros dias e esses primeiros tempos se transformam em longos anos de arbítrio e bruteza. Dessa toada macabra, resulta que:

\begin{abstract}
A repressão selvagem - as prisões em massa no estádio de Santiago e as execuções sumárias - institucionalizam-se pouco a pouco. As operações de limpeza da "lepra vermelha" teriam feito de 30000 a 50000 vítimas, segundo as estimativas realizadas durante o primeiro ano e 90000 chilenos (em uma população de aproximadamente 9 milhões de habitantes) teriam sido detidos. (IDEM, p. 306).
\end{abstract}

Como se isso fosse pouco, o governo Pinochet aplica o mais selvagem plano contra os direitos sociais da classe trabalhadora, que perde o seu poder aquisitivo de modo avassalador, sem se falar do incremento do desemprego e da ofensiva desmedida contra os serviços públicos, notadamente educação e saúde. A economia cresce à custa da classe que vive da venda de sua força de trabalho. Inaugura-se precocemente o advento das políticas neoliberais. O país andino se torna laboratório do modelo ultraliberal proposto por Milton Friedman e os Chicago Boys. A isso, eles chamam de "liberalização das forças de mercado".

\begin{tabular}{|l|l|l|l|l|}
\hline Revista Dialectus & Ano 2 & n.7 & Setembro-Dezembro 2015 & p. $104-126$ \\
\hline
\end{tabular}


Essa liberalização se combina com a repressão mais encarniçada. A jornalista Patrícia Verdugo conta essa história em sua expressão mais veemente e feroz. O seu objeto é "A caravana da morte", que, sob o comando do general Sergio Arellano Stark, durante meses aterroriza o Chile e transforma o deserto em cemitério de militantes de esquerda. A prática de queimar os corpos se incorpora a tradição do regime, sob o pretexto de que os cães, atraídos pelo cheiro dos cadáveres, não cavem buracos e revelem os mortos ao mundo.

Há histórias que beiram o estádio de alucinação. Veja-se o caso de Glória Benavente de Lavín. O seu marido presta depoimento aos seus algozes e não retorna. $\mathrm{O}$ testemunho de Glória Benavente é eloquente, demonstra o tamanho descomunal da violência:

Minha mãe gritou: "fuzilaram Cláudio!" Desse momento em diante tenho uma lacuna absoluta... É um dia da minha vida que não existe. Não sei o que aconteceu, só lembro que me levantei no dia seguinte com a imagem da irmã de Cláudio ajoelhada ao lado da minha cama, vestida de preto. (VERDUGO, 2001, p. 65).

Esse episódio é simbólico do que significa a caravana da morte. Os filhos de Cláudio só sabem da sua morte no momento em que Patrícia Verdugo empreende a sua investigação jornalística e chega até Glória e a sua triste sina, revelando como muitos fatos desses anos sombrios permanecem em uma zona de sombra. A lacuna absoluta já não existe, mas, decerto, ainda existem vazios, lapsos e janelas nessa história de fardo e de escuridão.

O livro de Patrícia Verdugo - que comprova que a Caravana da Morte é responsável de 72 execuções -, conduz alguns dos verdugos da ditadura pinochetista ao banco dos réus. O próprio Pinochet é declarado réu, embora morra sem ser objeto de sanção pela justiça chilena. Isso não impede que alguns de seus sequazes mais contumazes sejam julgados e punidos, como Manuel Contreras, chefe da Dirección de Inteligencia Nacional (DINA), a polícia política do regime.

Isabel Allende chega a escrever a Patrícia, comovida e agradecida a seu trabalho de penosa pesquisa. Na carta, a filha do primo-irmão do presidente deposto, declara: "Você escreve a história, não Pinochet e seus sequazes. Em nome de tantos desaparecidos e de tantos que sofreram, abraço-a. bendita seja entre todas as mulheres, Patrícia. Sua amiga, Isabel Allende".

Dilacerada pelos mesmos processos, a população do Uruguai, que, também, goza de uma tradição civilista e constitucionalista, se vê mergulhada em uma ditadura, meses antes dos funestos acontecimentos do Chile. Assim, em meados de 1973, os uruguaios 
testemunham a entrada em cena de um sistema de poder de corte militar, que principia com o fechamento do congresso nacional e tem o seu desfecho, pouco tempo depois, com a deposição do presidente Juan María Bordaberry. Assim, um país tido como "atípico", conforme recordam os liberais, como Rouquié (1984), se torna parte da linha típica de dominação militarista. A simples hipótese de triunfo eleitoral da Frente Ampla, ainda em 1971, já suscita a possibilidade de uma ação coordenada com o Brasil para impedir a posse do eleito, na chamada Operação Trinta Horas. A derrota da oposição adia os planos, mas não o desejo ávido de, em breve, realizá-los. Esse fato talvez desvele que a gloriosa tipicidade uruguaia, com efeito, tem os pés de barro.

Gramsci (1985) chama a atenção para o fato de que, na América do Sul e na América Central, existe "uma situação na qual o elemento laico e burguês ainda não alcançou o estágio de subordinação, à política laica do Estado moderno, dos interesses e da influência clerical e militar" (p. 24). Essa compreensão ajuda a entender porque mesmo em países, com solene tradição constitucionalista, a influência militar e clerical arquiva-se no corpo e no imaginário de estratos do mundo social, em particular, daqueles vinculados às classes dominantes e às camadas médias.

Em todos os casos, do Brasil à Argentina, passando por Chile e Uruguai, a articulação da cruz e da espada se encontra na base da liquidação das instituições da democracia representativa, ainda que o espectro do comunismo seja sempre utilizado para legitimar as iniciativas golpistas desses setores.

No caso do Uruguai, a estabilidade política é assegurada pelos laços profundos que ligam o Partido Colorado ao braço armado do Estado. Definitivamente, partido e exército se enlaçam ao longo da história. Não por acaso, os colorados governam o Uruguai, consecutivamente, por quase cem anos, amparados na influência militar. A crise estrutural que vive o país impede que as concessões sociais, marca das antigas províncias orientais, sigam como partes constituintes do Estado-previdência. Correlatamente, abre-se um hiato no interior da complexa síntese do "Estado de compromisso" e os antagonismos de classe adquirem ritmo próprio e fogem do controle estatal. As greves sacodem a ordem social e a estabilidade política se deteriora. As classes dominantes trocam a democracia representativa pela ditadura aberta como meio de preservar a ordem que lhes interessa. Impõe-se o que a historiografia batiza de "Estado de emergência". 4

\footnotetext{
${ }^{4}$ Sobre a evolução política dos acontecimentos, no Uruguai, vide Rouquié (1984).
}

\begin{tabular}{|l|l|l|l|l|}
\hline Rovista Dialectus & Ano 2 & n.7 & Setembro-Dezembro 2015 & p. $104-126$ \\
\hline
\end{tabular}


Os militares uruguaios também passam pelas escolas estadunidenses. De 1950 a 1970, 1723 deles estagiam nos EUA (ROUQUIÉ, 1984, p. 294). Não demora a que o exército assuma a dianteira da repressão ao movimento operário. Os sindicatos são perseguidos quase que simultaneamente à institucionalização do poder militar. A greve geral de quinze dias, organizada pela Confederação Nacional dos Trabalhadores (CNT), é derrotada. O caminho está aberto aos golpistas. Sob essa perspectiva, Rouquié assinala que a "militarização do Estado caminha ao lado da destruição das organizações representativas" (p. 298). O presidente Bordaberry, que apoia o fechamento do congresso e a militarização do Estado, prova do próprio veneno e é derrubado pelos militares em 12 de junho de 1976. Nesse período de domínio militar, as forças da ordem mais do que dobram e se mostram em toda a sua cruel imponência, como revela Rouquié:

A tortura torna-se um procedimento administrativo comum. Embora haja "desaparecidos", esse regime mata menos do que outros. Porém, 5000 prisioneiros políticos, 15000 cidadãos em liberdade vigiada e perto de 60000 que já passaram pela prisão atestam o bom funcionamento da máquina terrorista, sobre a qual restam dúvidas se não seria um fim em si própria. (ROUQUIÉ, 1984, p. 302).

Esse quadro talvez dê razão ao latino-americanista francês, quando ele classifica o sucessor do antigo Estado-previdência - transformado em simples aparelho ou órgão de repressão política - como Estado-guarnição. Nesse quadro, depois dos sindicatos e das organizações de esquerda (nomeadamente, dos grupos armados), as instituições educacionais (principalmente do ensino superior) se transformam "em um território dominado pelos militares". Em tais circunstâncias, não há de se surpreender com as sábias palavras do novo dirigente da faculdade de Agronomia: "É preciso suprimir a pesquisa, porque atrapalha o ensino". (Apud Rouquié, 1984, p. 303).

Eduardo Galeano, nesses tempos de apreensão, de violência brutal, de uso sistemático da tortura e de promoção da morte por motivações políticas, não se cansa de voltar os olhos para a sua terra natal, aludindo sempre à privação de liberdade a que estão submetidos os seus compatriotas. Durante muito tempo, ele persiste na recuperação crítica dessa época soturna. No livro "Os filhos dos dias", o escrito uruguaio escreve sobre o lugar da Operação Condor na vida do povo uruguaio, narrando o caso de Macarena Gelman:

A mãe de Macarena estava grávida dela quando os militares argentinos a mandaram para o Uruguai. A ditadura uruguaia se encarregou do parto, matou a mãe e deu a filha recém-nascida de presente a um chefe de polícia. Durante a infância inteira, Macarena dormiu atormentada por um pesadelo inexplicável, que se repetia noite após noite: era perseguida por homens

\begin{tabular}{|c|c|c|c|c|}
\hline QRovista Dialectus & Ano 2 & n.7 & Setembro - Dezembro 2015 & p. $104-126$ \\
\hline
\end{tabular}


armados até os dentes, e acordava chorando. O pesadelo deixou de ser inexplicável quando Macarena descobriu a verdadeira história da sua vida. E então ficou sabendo que ela havia sonhado, lá na infância, os pânicos de sua mãe: sua mãe, que a estava modelando no ventre enquanto fugia da caçada militar que acabou alcançando-a e a mandou a morte. (GALEANO, 2014, p. 64).

Mas ao lado da descrição desse thriller de terror, há um breve texto intitulado "O Reino do Medo", no qual, uma vez mais, o autor se refere ao local de nascimento. O relato é doloroso:

Hoje é o Dia contra a Tortura. ${ }^{5}$ Por trágica ironia, a ditadura militar do Uruguai nasceu no dia seguinte, em 1973, e transformou o país inteiro numa grande câmara de torturas. Os suplícios serviam pouco ou nada para arrancar informação, mas eram muito úteis para semear o medo, e o medo obrigou os uruguaios a viver calando ou mentindo. No exílio, recebi uma carta anônima: "É foda mentir, e é foda se acostumar a mentir. Mas pior que mentir é ensinar a mentir. Eu tenho três filhos". (IDEM, p.206).

Nota-se que a violência impõe o medo e o medo impõe a necessidade de mentir para sobreviver. Nesse contexto de arbítrio, a moral suprema não é que se deve falar a verdade; a única moral válida é de que não há lugar para verdade. Como, em tais condições, sobreviver humana e moralmente? Esse é o mote que guia a carta anônima citada por Galeano. ${ }^{6}$ De mais a mais, não há como não relacionar o texto do intelectual uruguaio - e o clima político no qual o autor se inspira - com um célebre poema de Carlos Drummond de Andrade intitulado Congresso Internacional do Medo. No poema, o bardo mineiro escreve:

Provisoriamente não cantaremos o amor, que se refugiou mais abaixo dos subterrâneos. Cantaremos o medo, que esteriliza os abraços, não cantaremos o ódio porque esse não existe, existe apenas o medo, nosso pai e nosso companheiro, o medo grande dos sertões, dos mares, dos desertos, o medo dos soldados, o medo das mães, o medo das igrejas, cantaremos o medo dos ditadores, o medo dos democratas, cantaremos o medo da morte e o medo de depois da morte, depois morreremos de medo e sobre nossos túmulos nascerão flores amarelas e medrosas. (DRUMMOND, 2012, p. 20).

Na situação vivida pelo Uruguai, o grande medo, antes de tudo, é o medo dos soldados, dos ditadores que, cotidianamente, vociferam e reprimem operários e camponeses, pobres e negros, estudantes e índios, mulheres e guerrilheiros, que, na longa noite do medo, se obstinam em resistir, a começar do momento em que o poder autocrático insinua os seus

\footnotetext{
${ }^{5} \mathrm{O}$ dia 26 de junho é o Dia contra a tortura.

${ }^{6}$ Em outro trabalho, Galeano (2001) observa que "No Uruguai existem de quatro a cinco mil presos políticos. Não é pouco. No começo, foram os guerrilheiros. Depois, os militantes dos partidos de esquerda. Depois, os sindicalistas. Depois, os intelectuais. Depois, políticos tradicionais. Depois, qualquer um”. (p. 124)

\begin{tabular}{|c|c|c|c|c|c|}
\hline Revista & Dialectus & Ano 2 & n.7 & Setembro-Dezembro 2015 & p. $104-126$ \\
\hline
\end{tabular}
}


primeiros passos. Essa resistência política não passa distraída pelo cinema de Costa-Gavras, que em seu filme "Estado de sítio" retoma um fato transcorrido ainda nos alvores da luta empreendida pela esquerda, antes da longa noite da ditadura se abater sobre o país. O filme, lançado em 1973, coincide com o golpe que cerra as portas do congresso nacional e prepara a maior repressão vivida pelo povo uruguaio. O tema do filme é a ação do grupo guerrilheiro Tupamaro, que sequestra um diplomata brasileiro e um agente da CIA. Durante os anos em que o poder ditatorial está instalado, os tupamaros combatem o regime discricionário, sem, no entanto, obter êxito. No máximo, conquistam vitórias táticas e colhem derrotam estratégicas. Somente quando a mobilização popular arrebenta o controle do aparelho de Estado militarizado é que o Uruguai atesta o ressurgimento das condições para o restabelecimento das liberdades democráticas. Nesse momento, o medo começa a ser derrotado.

No mesmo ano em que Bordaberry é deposto, no Uruguai, completando a obra iniciada três anos antes, quando o congresso nacional é dissolvido, os militares dão o golpe de Estado que impõe sete anos de ditadura na vizinha Argentina. O regime militar semifascista, implantado em 1976, impõe uma ordem de terror à população argentina. O golpe de Estado que abre caminho para o estabelecimento do poder ditatorial - é o quinto putsch desde 1930. No intervalo de tempo de 1930 a 1976, ocorrem golpes militares em 1955, 1962 e 1966, confirmando uma tradição de instabilidade política e de quebra de qualquer tradição constitucionalista. São cinco golpes de Estado em 46 anos, uma média de praticamente uma ruptura institucional a cada nove anos. Na memória portenha e dos demais grupos identitários argentinos, porém, nada pode ser comparado ao ocorrido a partir de 1976. É como se a história desse povo se dividisse antes e depois desse ciclo de terror. É como se todo o passado, de repente, se tornasse para todo o sempre inacessível. Por fim, é como se a história de um povo começasse centenas de anos depois de seu aparecimento.

Debruçando-se sobre os estudos acerca dessa experiência, há de se observar os pontos em comum com os demais episódios verificados nos países vizinhos, conforme se pode desprender - a título de ilustração - do trabalho de exame do caso argentino, levado a cabo por Alejandra Leonor Pascual, professora e pesquisadora da UNB. Para a autora de Terrorismo de Estado - a Argentina de 1976 a 1983,

Em março de 1976, os militares argentinos deram um golpe de Estado, justificando-se na necessidade de defender o país do desgoverno, da corrupção e do "flagelo comunista". A ideologia que predominava no âmbito castrense daquela época se inspirava na doutrina de segurança nacional. Originada nos Estados Unidos na época da chamada Guerra Fria,

\begin{tabular}{|l|l|l|l|l|}
\hline Qevista Qialectus & Ano 2 & n.7 & Setembro-Dezembro 2015 & p. 104-126 \\
\hline
\end{tabular}


disseminou-se para toda a América Latina a partir da formação de militares do continente em escolas e centros de treinamento norte-americanos. (PASCUAL, 2004, p. 19).

Constatam-se aí as mesmas características admitidas nos casos anteriormente estudados: a influência dos EUA, a segurança nacional funcionando como base jurídicofilosófica da usurpação militarista, as escolas estadunidenses atuando como polo de convergência do ideário anticomunista e a primazia de uma retórica salvacionista da parte dos militares ("defender o país do desgoverno"). Esse aparato ideológico, político e castrense, em nenhum momento coloca em dúvida a necessidade de preservar o sistema econômico. A forma preferencial de organização política, a democracia parlamentar, é contestada, mas jamais o sistema econômico. Desse modo, os regimes discricionários atuam como sentinelas do capital e a "ordem jurídica" por eles implantada se mostra compatível com a reprodução da lógica do capital. As suas baterias, então, se voltam contra as instituições representativas, contra os elementos de democracia proletária, existentes, e, finalmente, em franca guerra com relação a tudo que se associe, direta ou indiretamente, com a ideia de comunismo (socialismo, marxismo, luta de classes, proletariado, esquerda, sindicalismo etc.).

Se o Estado militar argentino, como quer nos fazer acreditar Rouquié (1984) desempenha "o papel de inversor das correntes sociais", essa inversão é sempre na direção de um estrato determinado das classes dominantes e o regime nascido da quartelada de 1976 apenas confirma essa tendência histórica. Basta que seja lembrado o período do ditador Videla, quando o seu ministro da economia, Martínez de Hoz, não se acanha em favorecer a oligarquia financeira.

No mais, na terra de Sam Martín, a retórica dos militares é análoga a dos demais países do cone sul. Para eles, trata-se de combater a subversão, entendendo esta como a ação de resistência empreendida pela esquerda. O chanceler e contra-almirante César Guzetti é taxativo quanto a esse entendimento: "Meu conceito de subversão refere-se às organizações terroristas de signo esquerdista. A subversão ou o terrorismo de direita não pode ser considerado como tal" (apud Pascual, 2004, p. 53). A sua abordagem é inteiramente coerente com a estratégia do Estado militar de pactuar com os grupos paramilitares da direita argentina para liquidar a resistência, armada ou não, referenciada nos agrupamentos de esquerda, que perdem muitos de seus quadros e militantes no combate a autocracia vigente.

Os números do genocídio argentino, nos sete anos de ditadura, são muito desencontrados. Reynaldo Bignone, um dos comandantes militares que dirigem os destinos do

\begin{tabular}{|c|c|c|c|c|}
\hline Revista Dialeatus & Ano 2 & n.7 & Setembro - Dezembro 2015 & p. $104-126$ \\
\hline
\end{tabular}


país, ao longo desse período, afirma que os generais-presidentes são responsáveis pelo assassinato de "apenas" 8000 civis. Provavelmente, muitas fossas comuns, nas quais está enterrada parte significativa dos desparecidos, permanecem desconhecidas. No início das investigações pós-ditadura, os cálculos alcançam o patamar de 13000 mortos e desaparecidos, mas, com o passar dos anos e o correr das pesquisas, organizações nacionais e internacionais de direitos humanos estimam que o número de mortos e desaparecidos alcance 30000 pessoas. Mais do que o odor de fotografias mofadas, há questões que dizem respeito a milhares de famílias que carecem de informações precisas com relação aos seus entes queridos. Esse é um drama ainda à cata de soluções.

$\mathrm{Na}$ Argentina, os campos de concentração, os corpos jogados no rio da Prata e no Atlântico, a morte lenta na tortura e o uso de crianças como "prendas de guerra" se conservam como legados forçados e motivam o aparecimento de movimentos muito peculiares, como os das mães e das avós da Plaza de Maio, signos da resistência popular aos desmandos da ditadura. Nesse quadro, a violência contra familiares de ativistas e presos políticos constitui uma das páginas mais trágicas do regime militar argentino. Esse é um regime em que nem as crianças são poupadas.

O depoimento de Pablo Diaz - pouco tempo depois da queda da ditadura - sobre a "Noite do Lápis", na qual crianças e adolescentes de 14 a 17 anos são torturadas ou torturadas e mortas (o que acontece com a maior parte delas) é um dos instantes de maior comoção da história recente do país platino. O repórter de uma revista descreve assim o depoimento de Pablo ao tribunal:

Seu relato, entre soluços, foi tão comovente e impressionante que os ventiladores elétricos no tribunal foram desligados para não perturbar o silêncio profundo da sala durante os 100 minutos do seu depoimento. (VEJA, 1985, p. 43).

As histórias que são contadas acerca desse período, na Argentina, primam pelo seu caráter pungente, tocante e trágico. Parafraseando Galeano, para que hoje não seja outro nome de ontem, essas histórias precisam ser conhecidas. Os antigos não podem esquecê-las. Os novos precisam conhecê-las. No filme "História oficial", o tema das crianças roubadas e entregues aos algozes de seus pais aparece em toda a sua imensa e catastrófica arquitetura. Estima-se que mais de quinhentas crianças se transformam em prendas de guerra durante os anos de chumbo argentinos. Os generais chamam a isso de "guerra suja", dando a entender que nessa guerra todos os métodos são válidos.

\begin{tabular}{|c|c|c|c|c|}
\hline Rovista Dialectus & Ano 2 & n.7 & Setembro - Dezembro 2015 & p. $104-126$ \\
\hline
\end{tabular}


Em cada história se vislumbra uma ferida aberta, mas todas elas pertencem a uma área comum, na qual cada um se vê representando o mesmo script lôbrego. O caso das amigas Silvina Parodi e Cecília testemunha a continuidade do passado na alma do presente. No belo texto "uma mulher conta", Eduardo Galeano relata que:

\begin{abstract}
Vários generais argentinos foram levados a julgamento por causa das façanhas que cometeram nos tempos da ditadura militar. Silvina Parodi, uma estudante acusada de atividades subversivas por viver protestando e criando caso, foi uma das muitas prisioneiras desaparecidas para sempre. Cecília, sua melhor amiga, prestou depoimento, diante do tribunal, no ano de 2008. Contou os suplícios que havia sofrido no quartel, e disse que tinha sido ela quem entregou o nome de Silvina, quando não conseguiu mais aguentar as torturas de cada dia e de cada noite. - Fui eu. Eu levei os verdugos até a casa onde Silvina estava. Eu vi quando ela saiu, aos empurrões, às coronhadas, aos pontapés. Eu escutei ela gritar. $\mathrm{Na}$ saída do tribunal, alguém se aproximou e perguntou a Cecília, em voz baixa: - E depois disso, como é que você faz para continuar vivendo? E ela respondeu, em voz mais baixa ainda: - E quem que disse que eu estou viva?. (EDUARDO GALEANO, 2014, p. 195).
\end{abstract}

Essas narrativas desvendam as relações de ruptura e de continuidade entre passado e presente e mostram como essas relações compreendem toda uma série de complexas mediações. Tomando-as de conjunto, talvez devêssemos dar razão a Marx e Engels (2001) quando eles dizem que o homem existe para que exista a história; a história existe para que exista a demonstração da verdade. Ao se debruçar sobre a história recente da Argentina, essa frase parece mais fulgurante do que se lida somente no contexto de A sagrada família, até porque no país platino a família, definitivamente, perde a sua aura de sagrada.

\title{
CONSIDERAÇÕES FINAIS
}

Não pretendo com este artigo esgotar o estudo sobre a especificidade da violência na América Latina, no contexto dos anos 1960 e 1970, quando múltiplos governos militares convertem a região em um espaço de amarga violência. Almejo tão somente trazer a lume histórias de violência que demandam uma vigorosa apreciação histórica, até como condição de enxergar no presente, mais do que uma simples ininterrupção do passado; mas enxergar nele, antes de tudo, a possibilidade de encadeamento com um "novo tempo" no qual não haja lugar para "ridículos tiranos".

\footnotetext{
7 A história, às vezes, ironicamente, aparenta andar em círculo. Pedro Bordaberry, filho de Juan María Bordaberry se candidata a presidente pelo Partido Colorado, em 2014, e é flagrantemente derrotado; a Frente

\begin{tabular}{|c|c|c|c|c|}
\hline Qenista Dialectus & Ano 2 & n.7 & Setembro - Dezembro 2015 & p. $104-126$ \\
\hline
\end{tabular}
}


Há lacunas evidentes. Inclusive, alguns trabalhos, que focam diretamente o tema da violência, não estão contemplados neste estudo. Espero que ele seja tomado como uma provocação e que as pessoas se sintam impelidas a devassar as paredes do tempo e espreitar personagens, histórias e situações que não podem ser esquecidos ou simplesmente ignorados.

São tempos de queda e de dor, mas, à primeira vista, o importante, como no provérbio árabe, é que "não é mérito o fato de não termos caído e, sim, o de termos levantado todas as vezes que caímos". Digo à primeira vista porque se se aprende como se caiu, talvez se evite cair novamente.

\section{REFERÊNCIAS}

ANDRADE, Carlos Drummond. Sentimento do mundo. São Paulo: Companhia das Letras, 2012.

BOUVIER, M. Virgínia. El ocaso de um sistema: encrucijada em Paraguai. Asunción: Editora Nanduti Vive, 1988.

BRASIL NUNCA MAIS. Petrópolis, RJ: Editora Vozes, 1985.

FREIRE, Alípio; ALMADA, Izaías; PONCE, J.A de Granville (orgs.). Tiradentes, um presídio da ditadura - memórias de presos políticos. São Paulo: Scipione, 1997.

GALEANO, Eduardo. "Negócios livres, gente presa?". In: Vozes crônicas - "Che” e outras histórias. São Paulo: Global/Versus, 1978.

Os filhos dos dias. Porto Alegre: L\&PM, 2014.

GRAMSCI, Antonio. Os intelectuais e a organização da cultura. São Paulo: Círculo do Livro, 1985.

GULLAR, Ferreira. História de um valente. In: Gregório Bezerra- memórias. São Paulo: Boitempo, 2013.

HOBBES, Thomas. Leviatã. In: Os pensadores. São Paulo: Abril Cultural, 1983.

\footnotetext{
Ampla, que ameaça vencer a eleição de 1971 e abre uma nova fase da crise política no Uruguai, que desemboca no golpe de 1973, se encontra em seu terceiro mandato consecutivo na presidência da república; Raúl Fernando Sendic, atual vice-presidente, é filho do velho Raúl Sendic, líder Tupamaro, assim como Pepe Mujica, ex-presidente, que passa 14 anos nas prisões uruguaias, milita entre os tupamaros no tempo da ditadura. No Chile, o Partido Socialista de Allende governa atualmente o país, malgrado as diferenças do velho projeto do PS comparado com o projeto em vigor - encabeçado por Michelle Bachelet. No Brasil, a presidente é uma ex-militante da Colina e de VAR-Palmares, dois grupos que combatem a ditadura de arma na mão, em fins dos anos 1960 e começo dos anos 1970. No Paraguai, depois da queda de Fernando Lugo, o Partido Colorado está de volta ao governo. Os vivos parecem mortos e os mortos ressuscitam.
}

\begin{tabular}{|l|l|l|l|l|l|}
\hline Revita & Sialeatus & Ano 2 & n.7 & Setembro-Dezembro 2015 & p. $104-126$ \\
\hline
\end{tabular}


MARX, Karl; ENGELS, F. A sagrada família. São Paulo: Centauro, 2001.

PASCUAL, Alejandra Leonor. Terrorismo de Estado - a Argentina de 1976 a 1983.

Brasília: Editora da UNB, 2004.

POTTER, Phillip. Prefácio do ex-secretário-geral do conselho mundial de igrejas. In: Brasil: nunca mais. 32a Edição, Petrópolis/RJ: Editora Vozes, 2001.

QUEIROZ, Fábio José de. 1964: o dezoito de brumário da burguesia brasileira, São Paulo: Sundermann, 2015.

ROSSI, Clovis. Militarismo na América Latina. São Paulo: Brasiliense, 1980.

ROUQUIÉ, Alain. O Estado militar na América Latina. São Paulo: Editora Alfa-Ômega, 1982.

SANTOS, Miguel dos. A ditadura de Stroessner no Paraguai e o controle da oposição: os mecanismos usados pela ditadura stronista visando ao controle da oposição, 2013. Disponível em: < http://www.apers.rs.gov.be/>. Acesso em: 28/09/2015.

STRIK, Ben. Morrer para viver - a luta de Tito de Alencar Lima contra a ditadura brasileira. Holanda: Brasilhoeve, 2009.

TOLSTOI, Leon. Ana Karenina. V. 1. São Paulo: Nova Cultural, 1995.

VEJA. A noite do Lápis: São Paulo, n.810, PP 40-41, 14 de março de 1984. In "História da América através de textos” (Jaime Pinsky, org.). São Paulo: Contexto, 2001.

VERDUGO, Patrícia. A caravana da morte. Rio de Janeiro: Revan, 2001.

\section{FILMES:}

A história oficial, Europa Filmes, 2007.

Estado de sítio, revista do DVD n. 43, s/d.

\begin{tabular}{|c|c|c|c|c|}
\hline Q Rovita Dialectus & Ano 2 & n.7 & Setembro - Dezembro 2015 & p. $104-126$ \\
\hline
\end{tabular}

